\title{
Economic Impact Assessment of Improved Maize Adoption on Poverty: Case Study of Four West African Countries
}

\author{
Ygué Patrice Adegbola ${ }^{1 *}$, Baudelaire YF Kouton Bognon ${ }^{2}$ and Pélagie M Hessavi ${ }^{2}$ \\ ${ }^{1}$ Institut National des Recherches Agricoles du Bénin(INRAB), Benin \\ ${ }^{2}$ Centre International de Recherche et de Formation en Science Sociales (CIRFoSS), Benin
}

Submission: November 09, 2020; Published: November 23, 2020

*Corresponding author: Ygué Patrice Adegbola, Institut National des Recherches Agricoles du Bénin (INRAB), Benin

Abstract

This study provides a consistent estimate of the impact of the adoption of the improved maize varieties on Poverty reduction, using three econometric approach (ATE, LATE, MTE) estimation techniques. It uses cross-sectional data of 1069 farmers from four West African country. Results show that the adoption of the improved maize varieties has a positive and statistically significant impact on average annual per capita household expenditure. Specifically, the empirical results suggest that adoption of improved maize varieties helped raise household per capita household expenditure by an average of 15.72 CFA. The adoption of improved maize varieties reduced the incidence and intensity of poverty by 7.44 and 8.33 respectively in all country.

Keywords: Welfare, MTE, Impact, Maize, West Africa

\section{Introduction}

Growth in agricultural output is one of the most effective means to address poverty in the developing world. Maize represents life to more than 300 million of Africa's most vulnerable people and is Africa's most important cereal crop [1]. In Africa, about $70 \%$ of people and $80 \%$ of the poor live in rural areas and depend mainly on agriculture for their livelihood [2]. The agricultural sector has seen a sharp decline in productivity rates in recent years [3]. This situation is due to a set of constraints including the decline of soil fertility, the use of rudimentary tools, the application of unsuitable technical itineraries and the low access of producers to inputs, especially seeds of improved varieties.

Maize is the main cereal involved in the diet of populations in West Africa (Adjanohoun et al. 2012). It accounts for $42 \%$ of the dietary energy intake (FAO, 2012) [4], 32\% of total protein consumption and $68 \%$ of the daily per capita cereal consumption (FAO, 2012).

It is also the most energetic cereal (Charcosset \& Gallais, 2009) and the most economical from the point of view of production [5]. Between 2005 and 2014, production, mainly for human and animal consumption, increased from $3,888,639$ tons to $6,287,216$ tons (FAO, 2016), a growth rate of nearly $62 \%$ in 10 years. However, despite all the efforts made, the maize supply is far from meeting the ever-increasing demand and yields are becoming lower due to frequent climatic disturbances. It is therefore clear that the main constraint facing the maize industry is its low productivity. This constraint is fundamentally due to the improved varieties little used by the producers (MAEP, 2014). Thus, to contribute to the improvement of maize yield, it is necessary to substitute the local varieties which represent the essential of the plant material used (Missihoun et al. 2012) by the improved varieties with high yield potential [6]. It necessary to demonstrate to farmers the contribution of adopting improved maize seed on human welfare. The main objective of this study is to analyze the economic impact of adopting improved maize on poverty and welfare in West African zone.

The study estimated an econometric model to assess the potential impact of improved maize adoption on farmer's welfare in four West Africa countries (Benin, Burkina-Faso, Ivory Coast and Mali).

This paper differs from the earlier economic research on African agriculture in the two ways. First, it quantifies improved maize adoption impact on maize farmer's welfare for four maize producer countries in West Africa zone. Second, this paper compares three econometric approach to estimate the effect IMV adoption on farmer's welfare. 
The remaining part of the paper is structured as follows. Methodological framework is discussed in section 2. Section 3 discusses both descriptive and empirical analysis results and section 4 concludes the paper.

\section{Methodology}

\section{Conceptual framework}

Several methods are developed to assess counterfactuals, drawing on the impact evaluation literature ${ }^{1}$. This study uses the "potential outcomes framework" developed by Rubin [7] to estimate the counterfactuals and compute the average impact of the adoption of improved maize on the observed outcome variable, here household expenditure. To describe the concept of "potential results", let us consider $Y_{i}$ as the observed outcome variable, of a producer $i$, who either does or does not adopt the improved maize varieties. Let $A_{i}$ be the decision to adopt, to be taken in such a way that $A_{i=1}$ if the producer adopted the improved maize varieties and $A_{1}=0$ if he did not. By supposing that the equation of outcome variable depends on the observed and non-observed factors, and by using the notation of classical regression, the expenditure $Y_{i}$ can be written as follows :

$$
Y_{i}=\lambda+\gamma x_{i}+\beta A_{i}+\varepsilon_{i}, \quad E\left(\varepsilon \mid \lambda, \gamma, \beta, x_{i}, A_{i}\right)=0
$$

where $\boldsymbol{\lambda}, \boldsymbol{\gamma}$ and $\boldsymbol{\beta}$ are unknown parameters to be estimated; $x_{i}$ are independent variables; and $\varepsilon_{i}$ the error term. $\boldsymbol{\beta}$ is the mean causal impact of $\mathrm{A}$ on $\mathrm{Y}$ in all observation units.

There are three main potential sources of bias in the programme impact measurement [8]. First of all, adopters are likely to be different from non- adopters in the distribution of their observed characteristics, leading to a bias due to the "selection on observables".

A second source of bias in the impact may arise when there is a dissemination of improved varieties knowledge within the communities. In the presence of the dissemination, the comparison between those adopting improved varieties and nonadopter in the same village is likely to underestimate the impact. A last source of bias is that those adopting improved varieties may be different from non-adopter in the distribution of non-observed characteristics (for example, in the capacity of the farmer that affects at the same time the decision to use improved varieties and the desire to look for new knowledge), which leads to the selection on non-observables. In the absence of an appropriate instrument to participate in the programme, it is difficult to control explicitly the selection of non-observable factors. Observable and nonobservable variables must be controlled, otherwise it is possible to wrongly conclude that there is a relation of causality between the use of improved maize varieties and the outome variables. Estimating the impact of farmers' participation in the activities on the revenues is therefore likely to be biased. Thus, the correct estimation of equation (1) needs the instrument $A_{i}$.
By admitting that the impact of adoption of improved maize on the outcome variable $(\beta)$ is heterogeneous, interaction terms were included in the model. The impact of adoption of improved maize varieties on the outcome variable $(\beta)$ is therefore rewritten as being a function of the independent variables $x$ and of the nonobserved heterogeneity (v).

$$
\beta=\alpha+(x-\bar{x}) \delta+v_{i} \quad E\left(v_{i} \mid x_{i}\right)=0
$$

Where $\bar{x}$ is a vector of sample means of $\mathrm{x}$.

By replacing the value of $\beta$ given by equation (2) in equation (1), the estimation model is presented as follows:

$$
Y_{i}=\lambda+x_{i} \gamma+\alpha A_{i}+A_{i}\left(x_{i}-\bar{x}\right) \delta+A_{i} v_{i}+\varepsilon_{i}
$$

Using the method of the instrumental variable to estimate the impact of adoption of improved maize on the outcome requires the presence of $A_{i} v_{i}$ in the error term of equation (3). According to Dimara \& Skuras (2003), the decision of a producer to adopt or not to adopt is determined by the expected utility resulting from the difference between the expected services from the adopter and the non-adopter. Producers, by taking into account their own non-observed gain, and exogenous variables $x$ may auto-select themselves. This leads to a correlation between $A_{i} v_{i}$ and $z$. The conditional value expected of $A_{i} v_{i}$ given by $(z, x)$, can be written as follows:

$$
E\left(A_{i} v_{i} \mid x_{i} z\right)=E\left(v_{i} \mid A_{i}=1, z\right) \operatorname{Pr}\left(A_{i}=1 \mid z\right) \neq 0
$$

Wooldridge [9] demonstrated that:

$$
E\left(A_{i} v_{i} \mid x_{i} z\right)=\varnothing_{i}\left(\theta_{0}+x_{i} \theta_{1}+z_{i} \theta_{2}\right)
$$

where $\varnothing_{i}($.$) is a standard probability density function and the$ correctional function.

The equation (3) can therefore be rewritten as follows:

$$
Y_{i}=\lambda+x_{i} \gamma+\alpha A_{i}+A_{i}\left(x_{i}-\bar{x}\right) \delta+\rho \varnothing_{i}\left(\hat{\theta}_{0}+x_{i} \hat{\theta}_{1}+z_{i} \hat{\theta}_{2}\right)+\varepsilon_{i}
$$

\section{Model specification}

The objective of this study is to estimate what the situation of the producer who adopt IMV would have been if they did not choose to adopt it. To solve the problem of selection bias and generate estimations with fewer possible biases at the level of the impact results, and the counterfactual approach based on the method of instrumental variables (VI) $[7,10]$, was used.

Learning from Wooldridge [9], the heterogeneous model of the impact of adoption of improved maize varieties on the households expenditure for instance presented by equation (6) was estimated in two steps.

The first step consisted of estimating a probit model of the factors that influence the probability to adopt improved maize varieties on the exogenous variables $\mathrm{x}$ and $\mathrm{z}$. The exogenous variables $\mathrm{x}$ is common to the adoption and households expenditure 
equation while the exogenous variables z belong exclusively to the adoption equation. This "exogeneity" restriction of the variables $\mathrm{z}$ is determining for the estimation of the household expenditure model to be consistent. The specification of the model of adoption is presented as follows:

$$
\text { Ai }=\delta+\alpha_{1} \text { dmarche }+\alpha_{2} \text { Nnatsol }+\alpha_{3} \text { Agroup }+\alpha_{4} \text { Na exp } r i+\alpha_{5} \text { Supdispo }+
$$$$
\alpha_{6} \text { Taillem }+\alpha_{7} \text { Narvil }+\alpha_{7} \text { Npriprod }+\varepsilon_{i}
$$

In the second step, the impact model of the adoption of IMV on the household of equation (6) was estimated. In this study, to correct the problem of noncompliance we use the instrumental variable (IV) approach. The variant of the IV approach adopted in this study is the local average treatment effect (LATE), introduced by Imbens \& Angrist [11] and is estimated as follows:

$$
L A T E=E\left(Y_{1 i}-Y_{0 i} \mid t_{1}=1\right)=\frac{E(y \mid z=1)-E(y \mid z=0)}{E(t \mid z=1)-E(t \mid z=0)}
$$

Where $\mathrm{z}$ is an instrument, indicating the adoption status variable, with $\mathrm{z}=1$ if the farmer was adopted IMV and $\mathrm{z}=0$ otherwise. Note that, $t_{1}$ is the treatment status of a farmer who was adopted IMV and $t_{1}=0$ if the farmer was not adopted IMV. LATE parameter gives the treatment effect only for those who decide to participate because of a change in $\mathrm{z}$, and they are often referred to as compliers in the impact assessment literature [12]. The mean impact of the adoption of IMV on poverty in the subpopulation of the compliers is given by Imbens \& Angrist [11], Imbens \& Rubin (1997). In this study, for the LATE estimation, the estimator proposed by Abadie [13] was used. This estimator is a generalization of the one proposed by Imbens \& Angrist [11] and for which the randomness of the instrument is not required or instrument is independent from $y_{1 i}$ and $y_{0 i}{ }^{2}$ conditionally from $x$. This estimator requires using at least an instrument $\mathrm{z}$ that affects directly the status of adoption but indirectly the results $y_{1 i}$ and $y_{0 i}$ once the independent variables $x$ are controlled.

The instrumental variable, in this study, is the knowledge the existence of improved maize varieties 0 with $z=1$ for the producers who know of the existence of improved maize varieties and $z=0$ for the producers who don't. In fact, the choice of this instrument is justified by the fact that knowing the existence of improved maize varieties can influence adoption of improved maize varieties. It is the producers who are aware of the existence of improved maize varieties that can be use it. On the contrary, the fact of being aware of the existence of improved maize varieties does not influence directly the household expenditure. A producer may be aware of the existence of improved maize varieties and still not adopt improved maize varieties. Thus, to adopt improved maize varieties, it is not enough to be aware of its existence. In summary, being aware of the existence of the improved maize varieties may influence its adoption but does not influence directly the household expenditure. Thus, this variable respects the definition of the instrument as presented by Abadie [13] and Heckman [14].

According to Abadie [13] and Lee [15], the average impact for the sub-population of potential participants (LATE) can be used from the function of Local Average Response Function (LARF) 》 defined by $f(x, t)=E\left(y \mid x, a, a_{1}=1\right)$. With $f(x, t)$ the LARF. Thus:

$$
\begin{aligned}
& \operatorname{LATE}_{\text {laf }}=\frac{1}{p\left(t_{1}=1\right)} \sum_{i=1}^{n_{i}} \hat{k}_{i} h(y i, x i, \hat{\theta}) \\
& \widehat{\operatorname{LATE}}_{\text {larf }}=\frac{1}{p\left(t_{1}=1\right)} \sum_{i=1}^{n_{1}} \hat{k}_{i} \cdot h\left(y_{i}, x_{i}, \widehat{\theta}\right) \mathrm{With} \quad \hat{k}_{i=1-\frac{z_{i}}{p\left(t_{1}=1\right)}}
\end{aligned}
$$
complier weight,

$h(y i, x i, \hat{\theta})=f(x, 1, \hat{\theta})-f(x, 0, \hat{\theta})$ and $\hat{\theta} \quad$ a parameter to be estimated by the method of ordinary least squares (OLS).

In addition to the instrumental variable introduced in the impact model, other independent variables were introduced based on the literature on the household expenditure determinants (for the expenditure model).

Since the treatment is self-determined by farmers, to account for potential endogeneity, the most plausible hypothesis is "selection for unobservable" [16]. Therefore, to eliminate both the bias induced by the observable and unobservable characteristics and the treatment variable, the MTE was used. This approach unifies not only the literature of treatment effects but also provides a consistent economic explanation of LATE. According to Heckman [15], it is possible to define the MTE parameter as follow:

$$
\operatorname{MTE}_{(x, u)}=E\left(Y_{1}-Y_{0} \mid X=x, U_{A}=u\right)
$$

The MTE parameter, defined by a conditional expectation, is obtained independently of an instrument [17]. It is defined as the average income of adoption for individuals with observable characteristics $X=x$ and unobservable $U_{A}=u$. For individuals with a value close to zero, the MTE is the expected effect of treatment on individuals who have unobservable characteristics that make them more likely to adopt improved varieties and who would have adopted even if $U_{A}(Z)$ utility is low.

\section{Data collection}

The data used for this study was collected by national partners of West and Central African Council for Agricultural Development (WECARD) in Benin, Burkina Faso, Ivory Cost and Mali. Household data on income, household and production characteristics were collected from 1,068 maize framers randomly selected in 4 countries (Benin, Burkina Faso, Ivory Cost and Mali). These countries are amongst maize producing countries in West Africa and are all in the same agro-ecological zones. In total, the survey was conducted in 15 districts across the four countries. In each country, districts were chosen to get a wide representation of farms across vulgarization zone. In each selected district, survey was conducted on randomly selected maize farming households. The number of surveyed households varied from country to country. A sample of 252 households were randomly chosen in Benin, 385 in Burkina Faso, 225 and 207 in Ivory Cost and Mali, respectively. The number of surveyed households per adoption status and per country is shown in Table 1 . The data collected at farm-level was for the season 2016-2017. The data include :

\footnotetext{
$2 y_{i i}$ and $y_{0 i}$ represent respectively the variable of interest (the household expenditure for example) if the producer has adopted improved maize varieties or not.
} 
a) the socio-economic characteristics of the agricultural households;
b) the characteristics of the farms;
c) the quantity of inputs;
d) the value of outputs; and
e) the farmer's adoption status.

Table 1: Sample size per Adoption Status per country.

\begin{tabular}{|c|c|c|c|}
\hline \multirow{2}{*}{ Countries } & \multicolumn{2}{|c|}{ Adoption Status } & \multirow{2}{*}{ All Farmers } \\
\cline { 2 - 3 } & Adopters & Non-Adopters & \\
\hline Benin & 185 & 67 & 252 \\
\hline Burkina Faso & 242 & 143 & 385 \\
\hline Ivory Coast & 91 & 134 & 225 \\
\hline Mali & 192 & 15 & 207 \\
\hline Total & 710 & 359 & 1069 \\
\hline
\end{tabular}

Source: CORAF Survey data, 2017.

\section{Data analysis}

Two models were used for estimation. At the first stage, we introduce based on the literature on the adoption of IMV determinants and finally the socio-economic variables. This first model (adoption Model) is estimated with Probit regression using Stata Software. At the second stage, based on the literature on the expenditure we integrated determinants into the model. The impact model are estimated using a MTE. For each of these models, we also estimated separately for adoption and impact model.

The estimation model consists of two dependent variables: adoption and household expenditure. The adoption variable indicated whether the farmer adopted or rejected at least one maize storage innovation. Household expenditure measured the total amount of money which the household devoted to consumption during the survey year. Sample means for household expenditure for each country are computed for adopters and nonadopters of IMV and reported in Table 2. Descriptive statistics show that farmers who adopted IMV spent on average more on their house consumption than did non-adopters.
Table 2: Average daily per capita household expenditure per country (in US\$4).

\begin{tabular}{|c|c|c|c|c|}
\hline \multirow{2}{*}{ Countries } & \multicolumn{2}{|c|}{ Adoption Status } & All & Poverty Line \\
\cline { 2 - 4 } & Adopters & $\begin{array}{c}\text { Non- } \\
\text { Adopters }\end{array}$ & Farmers & (in \$) \\
\hline Benin & 2.65 & 1.77 & 2.42 & 1.03 \\
\hline Burkina Faso & 1.61 & 1.46 & 1.55 & 0.69 \\
\hline Ivory Coast & 1.28 & 1.25 & 1.26 & 0.66 \\
\hline Mali & 0.79 & 0.86 & 0.79 & 0.3 \\
\hline Average & 1.62 & 1.42 & 1.55 & 0.68 \\
\hline
\end{tabular}

The study adopted the relative poverty line ${ }^{3}$ which was calculated as $2 / 3$ of the mean per capita household expenditure. The calculated poverty line for all countries is equal to $\mathrm{z}=379.49$ CFA (\$0.68) per day. Households with per capita expenditure below this poverty line are classified as poor and non-poor otherwise.

\section{Results}

\section{Descriptive statistics by adoption status and test of mean difference}

The result of the descriptive statistics for some selected variables by adoption status is presented in Table 3 . The statistically significant differences in the mean of some of the variables between adopter and non-adopter show that the two groups differ in some characteristics. Hence, the use of mean difference between the outcomes of the adopter and non-adopter will not have any causal interpretation. It also presents the statistical test of the average difference between the two groups. This allows us to know the variables likely to influence the impact indicators. Generally, these results show that the two groups (adopter and non-adopter of IMV) presented many similarities in socioeconomic characteristics, except for the variables where the mean difference was statistically significant. Therefore, we can suspect that the differences observed in the household expenditure were due to this significant variable.

To correct these differences, these variables were introduced in the impact adoption model of IMV in addition to other determinants of the expenditures and poverty.

Table 3: Descriptive Statistics of variable used in regression.

\begin{tabular}{|c|c|c|c|c|c|c|c|c|c|c|c|c|c|c|c|}
\hline \multirow{3}{*}{ Variables } & \multicolumn{6}{|c|}{ Coastal Area } & \multicolumn{6}{|c|}{ Sahelian Zone } & \multirow{2}{*}{\multicolumn{3}{|c|}{ All Country $(\mathrm{N}=1068)$}} \\
\hline & \multicolumn{3}{|c|}{ Benin $(N=251)$} & \multicolumn{3}{|c|}{ Ivory Coast $(\mathrm{N}=\mathbf{2 2 5})$} & \multicolumn{3}{|c|}{ Burkina Faso $(\mathrm{N}=386)$} & \multicolumn{3}{|c|}{ Mali (N=206) } & & & \\
\hline & $\begin{array}{l}\text { ADO } \\
\text { PTER }\end{array}$ & $\begin{array}{c}\text { NAD } \\
\text { OPTER }\end{array}$ & Test stat & $\begin{array}{c}\text { ADO } \\
\text { PTER }\end{array}$ & $\begin{array}{c}\text { NAD } \\
\text { OPTER }\end{array}$ & $\begin{array}{l}\text { Test } \\
\text { stat }\end{array}$ & $\begin{array}{c}\text { ADO } \\
\text { PTER }\end{array}$ & $\begin{array}{c}\text { NAD } \\
\text { OPTER }\end{array}$ & Test stat & $\begin{array}{l}\text { ADO } \\
\text { PTER }\end{array}$ & $\begin{array}{c}\text { NAD } \\
\text { OPTER }\end{array}$ & Test stat & $\begin{array}{l}\text { ADO } \\
\text { PTER }\end{array}$ & $\begin{array}{c}\text { NAD } \\
\text { OPTER }\end{array}$ & Test stat \\
\hline $\begin{array}{l}\text { Per capita } \\
\text { annual } \\
\text { Household } \\
\text { expenditure } \\
\text { (US\$/ day) }\end{array}$ & 2.65 & 1.77 & & 1.28 & 1.25 & & 1.61 & 1.46 & & 0.79 & 0.86 & & 1.62 & 1.42 & \\
\hline
\end{tabular}

\footnotetext{
${ }^{3}$ The study uses the three poverty measures proposed by Foster et al. (1984) which is formulated as follows: ${ }^{p(\alpha)}=\frac{1}{n} \sum_{i+1}^{m}\left[\max \left(\frac{z-C_{i}}{z}, 0\right)\right]^{\alpha}$, wherezis the poverty line, ciis the per capita consumption expenditure of farmer $\mathrm{i}$, and $\mathrm{n}$ is the total number of farmers. According to Foster et al. [18], $\alpha$ is a policy parameter that takes on values of 1,2 , and 3.When $\alpha$ is 1 , it gives the headcount index, which is the proportion of poor farmers in the population. When it is 2 , the result of the analysis provides the poverty deficit or gap index. When it is 3 , it gives the poverty severity index which signifies the level of income inequality in the population.
} 


\section{International Journal of Environmental Sciences \& Natural Resources}

\begin{tabular}{|c|c|c|c|c|c|c|c|c|c|c|c|c|c|c|c|}
\hline Age (year) & 45,24 & 42,80 & $-1,49$ & 47,21 & 42,95 & $-2,66^{* * *}$ & 40,58 & 39,45 & $-1,04$ & 49,43 & 43,66 & $-1,84^{*}$ & 45,04 & 41,56 & $-4,65^{* * *}$ \\
\hline $\begin{array}{l}\text { Alphabetisa- } \\
\text { tion }\end{array}$ & 78,13 & 21,88 & 0,16 & 58,18 & 41,82 & $9,50^{* * *}$ & 73,33 & 26,67 & $9,77^{* * *}$ & 91,43 & 8,57 & 0,11 & 73,70 & 26,30 & $7,39^{* * *}$ \\
\hline Household size & 6,58 & 4,01 & $-4,51^{* * *}$ & 4,63 & 6,28 & $3,79^{* * *}$ & 5,54 & 5,12 & $-1,52$ & 11,44 & 7,8 & $-2,91^{* * *}$ & 7,29 & 5,46 & $-6,81^{* * *}$ \\
\hline $\begin{array}{l}\text { Active } \\
\text { Household } \\
\text { size }\end{array}$ & 2,65 & 1,62 & $-1,97^{* *}$ & 3,94 & 5,22 & $3,58^{* * *}$ & 5,86 & 5,13 & $-1,64$ & 7,76 & 3,86 & $-3,47^{* * *}$ & 5,29 & 4,46 & $-3,08^{* * *}$ \\
\hline $\begin{array}{l}\text { Years of expe- } \\
\text { rience in maize } \\
\text { production } \\
\text { (year) }\end{array}$ & 21,6 & 21,32 & $-0,18$ & 36,40 & 18,74 & $-1,97^{* *}$ & 15,13 & 13,41 & $-1,65^{*}$ & 21,07 & 18,2 & $-0,73$ & 21,15 & 17,08 & $-1,95^{*}$ \\
\hline $\begin{array}{l}\text { Education } \\
\text { level }\end{array}$ & 75,56 & 24,44 & 1,48 & 52,38 & 47,62 & $5,17^{* *}$ & $63,74 \mid$ & 36,26 & 0,10 & 92,00 & 8,00 & 0,02 & 68,56 & 31,44 & 1,54 \\
\hline $\begin{array}{l}\text { Membership } \\
\text { of a group or } \\
\text { association of } \\
\text { maize farmers } \\
(\%)\end{array}$ & 80,00 & 20,00 & $3,39^{*}$ & 51,16 & 48,84 & $6,63^{* *}$ & 68,99 & 31,01 & $12,60^{* * *}$ & 95,09 & 4,91 & $6,23^{* *}$ & 75,25 & 24,75 & $48,19^{* * *}$ \\
\hline $\begin{array}{l}\text { Maize as main } \\
\text { culture (\%) }\end{array}$ & 82,17 & 17,83 & $16,34^{* * *}$ & 41,72 & 58,28 & 0,39 & 65,76 & 34,24 & $2,78^{*}$ & 88,81 & 11,19 & $8,81^{* * *}$ & 68,21 & 31,79 & $3,07^{*}$ \\
\hline $\begin{array}{l}\text { Maize farm } \\
\text { size (ha) }\end{array}$ & 2,28 & 1,08 & $-2,46^{* *}$ & 2,57 & 3,20 & 1,38 & 4,24 & 4,17 & $-0,07$ & 2,95 & 3,23 & 0,35 & 3,17 & 3,19 & 0,06 \\
\hline $\begin{array}{l}\text { Special train- } \\
\text { ing received } \\
\text { on the use } \\
\text { of improved } \\
\text { varieties }\end{array}$ & 75,00 & 25,00 & 0,17 & 44,44 & 44,44 & $6,73^{* * *}$ & 68,07 & 31,93 & 2,00 & 99,04 & 0,96 & $12,28^{* * *}$ & 76,71 & 23,29 & $26,33^{* * *}$ \\
\hline $\begin{array}{c}\text { Contact with } \\
\text { Projects / } \\
\text { NGOs (\%) }\end{array}$ & 75,00 & 25,00 & 0,07 & 42,86 & 57,14 & 0,03 & 71,74 & 28,26 & 1,76 & 98,21 & 1,79 & $39,55^{* * *}$ & 86,96 & 13,04 & 70,37 \\
\hline
\end{tabular}

\section{Impact of IMV adoption on household expenditure}

The results of the estimation of the impact of the adoption of at least one IMV on household expenditure are presented in Table 4. The Fisher test showed that the models are globally significant at the $1 \%$. In addition, the variation in household expenditure is explained by $54 \%$ of the explanatory variables in all the subzones. This rate was $47 \%$ and $56 \%$ respectively in Benin and Côte d'Ivoire; 67\% and 61\% respectively in Burkina Faso and Mali.

The results of the estimation show that variables such as, adoption status, secondary level, distance from village to city, Years of experience in maize production and contact with at least one extension service are all significant at least 10\% (Table 4).
Together, they determine the variation of the adoption of IMV on household expenditure. The average impact of the adoption of IMV on household expenditure of a randomly selected maize producer is $14.95 \%$ and significant at the $5 \%$ threshold for all sub-areas. In other words, for an adopter of the improved variety randomly selected as a whole, the relative difference in expected household expenditure is about $14.95 \%$. The highest average impact was observed in Benin in the coastal sub-zone (12.32\%) and in Mali in the Sahel sub-zone (16.43\%). In addition, compared to non-adopters of improved varieties of maize, the household expenditure of adopters increases by about $15.72 \%$ (MTT) in all sub-areas (Table 5). 
Table 4: Estimated coefficient of the MTE Estimation for household per capita expenditure.

\begin{tabular}{|c|c|c|c|c|c|}
\hline \multirow{2}{*}{ Variable } & \multicolumn{2}{|c|}{ Coastal Area } & \multicolumn{2}{|c|}{ Sahelian Zone } & \multirow{2}{*}{$\begin{array}{l}\text { All Countries } \\
(\mathrm{N}=1068)\end{array}$} \\
\hline & Benin $(N=202)$ & Ivory Coast $(\mathrm{N}=188)$ & Burkina Faso $(\mathrm{N}=386)$ & Mali $(\mathrm{N}=206)$ & \\
\hline Adoption status & $1,54^{* *}$ & $0,85^{* * *}$ & $0,72^{* * *}$ & $8,30^{* * *}$ & $0.48^{* *}$ \\
\hline Age & $0,58^{* * *}$ & 0.21 & 0.13 & $-0,00$ & 0,00 \\
\hline Sex & $-0,38$ & 0.34 & $0,57^{*}$ & $-0,15$ & 0,05 \\
\hline Primary level & $-1,63^{* * *}$ & $0,16^{* *}$ & $0,21^{* *}$ & 0,03 & 1,21 \\
\hline Secondary level & 0.4 & $0,22^{* *}$ & 0,08 & 1 & 0.26 \\
\hline Poverty status & $-0,96^{*}$ & $-0,58^{* * *}$ & $-0,21^{* *}$ &,$- 24^{*}$ & $-0,82^{* * *}$ \\
\hline $\begin{array}{l}\text { Distance from village to } \\
\text { town }(\mathrm{km})\end{array}$ & $-0,97^{*}$ & $-0,14^{* *}$ & $-0,25^{* *}$ & $-0,05$ & $-0,81^{* * *}$ \\
\hline $\begin{array}{l}\text { Years of experience in maize } \\
\text { production (year) }\end{array}$ & $1,02^{*}$ & $0,02^{* *}$ & $0,01^{*}$ & $2,01^{*}$ & $0,04^{* *}$ \\
\hline Maize farm size (ha) & 0,06 & 0,00 & 0,00 & $1,77^{* * *}$ & 0,00 \\
\hline $\begin{array}{l}\text { Income from farm activities } \\
\text { (FCFA) }\end{array}$ & 0,11 & $0,32^{*}$ & $0,06^{*}$ & $-0,18^{* * *}$ & 0,3 \\
\hline $\begin{array}{l}\text { Membership of a group or } \\
\text { association of maize farmers }\end{array}$ & $-0,53$ & $0,29 * *$ & $-0,13$ & $0,32^{* *}$ & 0,45 \\
\hline Marital status & 0,79 & $-0,13$ & 0,20 & 0,13 & $0,91^{*}$ \\
\hline Active Household & 0,02 & 0,04 & 0,17 & 0,10 & 0,20 \\
\hline $\begin{array}{l}\text { Contact with service exten- } \\
\text { sion }\end{array}$ & $-0,06$ & $0,11^{* *}$ & $0,19^{* *}$ & $0,40^{* * *}$ & $0,70^{* * *}$ \\
\hline Constante & $-6,38$ & 8,71 & $6,52^{* * *}$ & 2,59 & 1,37 \\
\hline Impact on population & $12,32^{* * *}$ & $8,57^{*}$ & $3,30 * *$ & $16,43^{*}$ & $14,95^{* *}$ \\
\hline Impact on adopters & $13,65^{* * *}$ & $9,66^{*}$ & $3,57^{* *}$ & $17,04 *$ & $15,72^{* *}$ \\
\hline Impact on non adopters & $7,11^{* * *}$ & $7,94^{*}$ & $2,84^{* *}$ & $8,66^{*}$ & $13,37^{*}$ \\
\hline Number of Observations & 202 & 188 & 386 & 206 & 1068 \\
\hline $\mathbf{F}$ & $3,94 * * *$ & $10,06^{* * *}$ & $12,20^{* * *}$ & $8,27 * * *$ & $10,88^{* * *}$ \\
\hline Adj R-Squared & 0,23 & 0,44 & 0,29 & 0,38 & 0,16 \\
\hline
\end{tabular}

Table 5: Impact of IMV adoption on household annual per capita expenditure.

\begin{tabular}{|c|c|c|c|c|c|}
\hline \multirow{2}{*}{ Variable } & \multicolumn{2}{|c|}{ Coastal Area } & \multicolumn{2}{|c|}{ Sahelian Zone } & \multirow{2}{*}{ All Countries $(\mathrm{N}=1068)$} \\
\hline & Benin $(N=202)$ & Ivory Coast $(\mathrm{N}=188)$ & Burkina Faso $(\mathrm{N}=386)$ & Mali $(\mathrm{N}=206)$ & \\
\hline \multicolumn{6}{|c|}{ ATE estimation with parametric functional form } \\
\hline ATE & $15,83^{* *}$ & $11,11^{*}$ & 6,10 & $19,45^{*}$ & $17,59^{* *}$ \\
\hline$A T T$ & $18,17^{* *}$ & $14,24^{*}$ & $8,24^{*}$ & $23,21^{*}$ & $20,20^{* * *}$ \\
\hline$A T U$ & $11,91^{*}$ & $12,09^{*}$ & $6,07^{* *}$ & 12,00 & $17,76^{*}$ \\
\hline LATE by LARF & $12,10 * *$ & $10,04 *$ & $2,21 * *$ & $16,10^{*}$ & $14,41^{* *}$ \\
\hline \multicolumn{6}{|c|}{ MTE Estimation } \\
\hline MTE & $12,32^{* * *}$ & $8,57^{*}$ & $3,30^{* *}$ & $16,43^{*}$ & $14,95^{* *}$ \\
\hline MTT & $13,65^{* * *}$ & $9,66^{*}$ & $3,57^{* *}$ & $17,04^{*}$ & $15,72^{* *}$ \\
\hline$M T U$ & $7,11^{* * *}$ & $7,94^{*}$ & $2,84^{* *}$ & $8,66^{*}$ & $13,37^{*}$ \\
\hline
\end{tabular}

${ }^{* * *} \mathrm{P}<0.01,{ }^{* *} \mathrm{P}<0.05,{ }^{*} \mathrm{P}<0.1$ 


\section{Poverty analysis of the farmers before and after the adoption}

The impact of adopting at least one IMV on the poverty status of producers was measured through the Foster-Greer-Thorbecke (FGT) [18] index at the sub-coastal zone level (Benin and Côte d'Ivoire), the Sahel sub-zone (Burkina Faso and Mali) and all sub-zones (Table 6). The results showed that the poverty rate in all sub-study areas is high (between 33\% and 40\%). Producers who have adopted at least one improved variety of maize are less poor than those who have not adopted it. Indeed, the adoption of IMV reduced the incidence of poverty by $4.37 \%$ and the intensity of poverty by $7.44 \%$ in all countries (Table 7 ). At the sub-zone level, the impact of the adoption of IMV on the poverty status of producers is more remarkable in the coastal sub-zone $(9.32 \%$ for Benin and 10.99 for Côte d'Ivoire) than in the Sahel sub-zones (3.29\% in Burkina Faso and 3.52\% in Mali). The adoption of these improved varieties increases yield, which improves producers' incomes and thereby contributes to poverty reduction.

Table 6: Poverty profile of the treated farmers before and after the intervention.

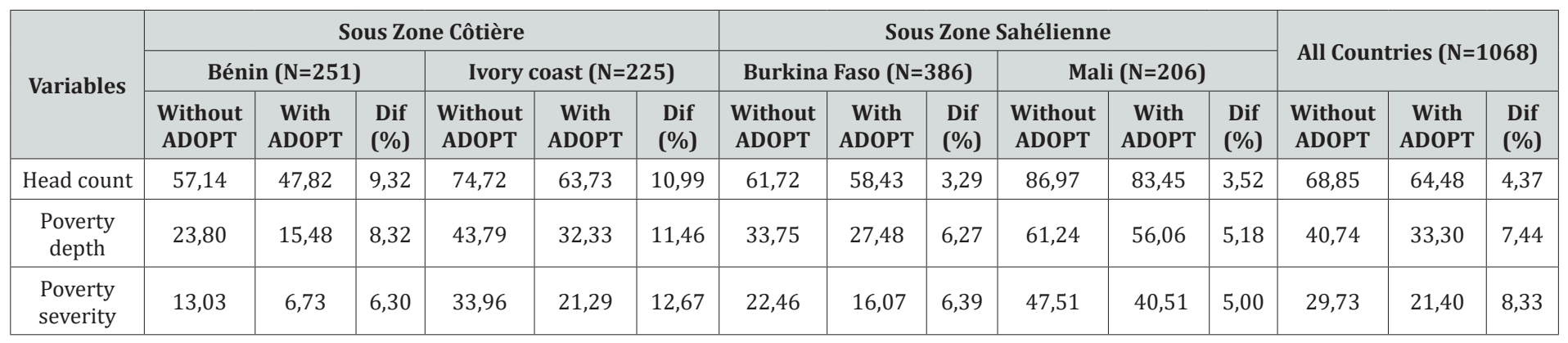

Table 7: Impact of IMV adoption on household annual per capita expenditure.

\begin{tabular}{|c|c|c|c|c|c|}
\hline \multirow{2}{*}{ Variable } & \multicolumn{2}{|c|}{ Coastal Area } & \multicolumn{2}{|c|}{ Sahelian Zone } & \multirow{2}{*}{ All Countries $(\mathrm{N}=1068)$} \\
\hline & Benin $(\mathrm{N}=202)$ & Ivory Coast $(\mathrm{N}=188)$ & Burkina Faso $(\mathrm{N}=386)$ & Mali $(\mathrm{N}=206)$ & \\
\hline \multicolumn{6}{|c|}{ ATE estimation with parametric functional form } \\
\hline ATE & $15,83^{* *}$ & $11,11^{*}$ & 6,10 & $19,45^{*}$ & $17,59^{* *}$ \\
\hline ATT & $18,17^{* *}$ & $14,24^{*}$ & $8,24^{*}$ & $23,21^{*}$ & $20,20^{* * *}$ \\
\hline ATU & $11,91^{*}$ & $12,09 *$ & $6,07^{* *}$ & 12,00 & $17,76^{*}$ \\
\hline LATE by LARF & $12,10^{* *}$ & $10,04^{*}$ & $2,21 *$ & $16,10^{*}$ & $14,41^{* *}$ \\
\hline \multicolumn{6}{|c|}{ MTE Estimation } \\
\hline MTE & $12,32^{* * *}$ & $8,57^{*}$ & $3,30^{* *}$ & $16,43^{*}$ & $14,95^{* *}$ \\
\hline MTT & $13,65^{* * *}$ & $9,66^{*}$ & $3,57^{* *}$ & $17,04^{*}$ & $15,72^{* *}$ \\
\hline MTU & $7,11^{* * *}$ & $7,94^{*}$ & $2,84^{* *}$ & $8,66^{*}$ & $13,37^{*}$ \\
\hline
\end{tabular}

${ }^{* * *} \mathrm{P}<0.01,{ }^{* *} \mathrm{P}<0.05,{ }^{*} \mathrm{P}<0.1$.

\section{Conclusion}

This study broadly assesses the impact of IMV on poverty reduction among smallholder maize farmers in four West African countries. Specifically, the study examines how the use of the IMV has impacted annual household per capita expenditure and reduces the poverty headcount index among rural smallholder maize farmers. The results reveal that all the observed poverty indices declined after the adoption. The adopter farmers have on average a higher total annual household expenditure compared to the non-adopter farmers. Results showed a significant impact of IMV adoption on household expenditure in West African rural households. These results confirm the potential and role of using agricultural technologies in improving household welfare. The use of improved technologies of maize production can be used as an effective instrument to fight again food insecurity and poverty. Studies on the impact of the adoption of maize on poverty in all maize-growing areas of Benin are necessary, so that substantial measures are taken.

\section{Acknowledgment}

The authors express their gratitude to all the staff of the West and Central African Council for Agricultural Research and Development (CORAF / WECARD) for the involvement and availability they have shown in putting the present mission in the better working conditions. Special thanks also go to the Executive Director of WECARD and Director of the National Center of 
Specialization on Corn (CNS-Maïs) for his accompaniment in the design and implementation of this study. We would like to thank the International Center for Research and Training in Social Sciences (CIRFoSS).

That the authorities of the General Directorate of the National Institute of Agricultural Research of Benin (INRAB), find here the expression of our deep gratitude for various scientific and administrative support. We would also like to thank the Burkina Faso, Mali and Ivory Coast work teams who actively contributed to the completion of this study.

\section{References}

1. La Rovere R, Abdoulaye T, Kostandini G, Guo Z, Mwangi W, et al. (2014) Economic, production and poverty impacts of investing in maize tolerant to drought in Africa. The Journal of Developing Areas 48(1) 199-225.

2. Olomola AS (2010) Enhancing productivity, income and market access of rural producers in Africa: the case of contract farming in Nigeria. Paper presented at the Inaugural National Science Foundation (NSF) Joint Workshop of the African Economic Research Consortium (AERC) and the International Growth Centre (IGC) held in Mombassa, Kenya.

3. CORAF/WECARD (2007) Manuel d'exécution du Programme de Productivité Agricole en Afrique de l'Ouest. p. 59.

4. Keya S, Rubaihayo P (2013) Progress in On-Farm Production and Productivity in the East African Community: 50 Years after Independence. International Symposium on Agriculture: EAC partner states at 50 years 5-7 November, 2013, Kilimo Trust Technical Paper No.8.

5. Nuss ET, Tanumihardjo SA (2011) Quality Protein Maize for Africa: Closing the protein Inadequacy Gap in Vulnerable Populations. American Society for Nutrition. Adv Nutr 2(3): 217-224.

6. Prudence DK, Jean NG, Louise A, Benedicte DZA, Patrice K (2015) Effect of conservation methods on the mineral contents of some maize varieties (Zea mays L.) produced in Côte d'Ivoire. Journal of Applied Biosciences 94: 8825-8834.

7. Rubin D (1974) Estimating Causal Effects of Treatments in Randomized and Non-randomized Studies. Journal of Educational Psychology 66(5): 688-701.

8. Godtland EM, Sadoulet E, De janvry A, Murgai R, et Ortiz O (2004) The Impact of Farmer Field Schools on Knowledge and Productivity: A Study of Potato Farmers in the Peruvian Andes. The University of chicago. p. 30

9. Wooldridge JM (2007) Instrumental variables estimation of the average treatment effect in correlated random coefficient models. In: Millimet D, Smith J, Vytlacil E (Eds.), Modeling and Evaluating Treatment Effects in Econometrics. Econometrics 21. Amsterdam.

10. Imbens GM, Woodridge JM (2009) Recent developments in the econometrics of program evaluation. J Econ Lit 47(1): 5-86.

11. Imbens GW, Angrist J (1994) Identification and estimation of local average treatment effects. Econometrica 62(2): 467-476.

12. Awotide BA, Karimov A, Diagne A, Nakelse T (2013) The impact of seed vouchers on poverty reduction among smallholder rice farmers in Nigeria. Agricultural Economics 44(6): 1-12.

13. Abadie A (2003) Semiparametric Instrumental Variable Estimation of Treatment Response Models. mimeo, Harvard University, December 2001.

14. Heckman JJ (2010) Building Bridges between Structural and Program Evaluation Approaches to Evaluating Policy. Journal of Economic Literature 48(2): 356-398.

15. Lee MJ (2005) Micro-Econometrics for Policy, Programme and Treatment Effects. Advanced Texts in Econometrics. Oxford University Press.

16. Diagne A, Nguezet PMD, Medgabé FMK, Alia D, Adégbola PY, Coulibaly $\mathrm{M}$, et al. (2012) The impact of adoption of NERICA rice varieties in West Africa. SPIA Pre-conference workshop; 28th IAAE conference, Foz do Iguaçu, Brazil, p. 58.

17. Heckman JJ, Urzua S, Vytlacil E (2006) Understanding instrumental variables in models with essential heterogeneity. Working Paper 12574.

18. Foster J, Greer J, Thorbecke E (1984) A Class of Decomposable Poverty Measures. Econometrica 52(3): 761-766.

\begin{tabular}{l} 
Your next submission with Juniper Publishers \\
will reach you the below assets \\
- Quality Editorial service \\
- Swift Peer Review \\
- Reprints availability \\
- E-prints Service \\
- Manuscript Podcast for convenient understanding \\
- Global attainment for your research \\
- Manuscript accessibility in different formats \\
( Pdf, E-pub, Full Text, Audio) \\
- Unceasing customer service \\
Track the below URL for one-step submission \\
https://juniperpublishers.com/online-submission.php \\
\hline
\end{tabular}

